\title{
Aspekte van 'n Christelike perspektief op fasette van die Geskiedwetenskap en die beoefening daarvan in ' $n$ veranderende Suid-Afrika
}

\author{
Elize S. van Eeden \\ Departement Geskiedenis \\ Potchefstroomse Universiteit vir $\mathrm{CHO}$ \\ POTCHEFSTROOM
}

\author{
C.J. Coetzee \\ Dept. Politieke Wetenskappe \\ Potchefstroomse Universiteit \\ vir $\mathrm{CHO}$ \\ POTCHEFSTROOM
}

\begin{abstract}
Aspects of a Christian perspective on some facets of History as a discipline and its practice in a changing South Africa

Within the framework and dynamics of a currently changing South Africa, not only History as a practised discipline but historians 100 - especially Christian historians are increasingly criticised from various quarters and/or faced with totally new' obstacles and questions. Alihough criticism in this sense constitutes nothing new per se, the fundamental character of changes sweeping the country (e.g. democratization. nation building, truth and reconciliation, societal restructuring) and the historio-political legacy of the recent past, re-accentuated the criticism that South African historiography has consistently proved to be subservient of a political ideology.

The objectives of this article are to highlight some former historical trends and current tendencies in Christian perspectives of the past and to discuss the question of how Christian historians and Christian History teachers can interact in a responsible and careful way with their subject by avoiding misrepresenting the truth and of hecoming (again?) the servants of just another ideology.
\end{abstract}

\section{Begronding van probleemstelling en aktualiteit van die probleem}

Die toenemende intensiteit en omvang van veranderings in Suid-Afrika veranderings wat in werklikheid reeds enkele dekades lank in swang is en tans, slegs in formele sin, voltrek word, laat die Suid-Afrikaanse Geskiedsbeoefening nie onaangeraak nie. Dit is des te meer die geval wanneer die taak en verantwoordelikheid van die Christelike historikus ter sprake gebring word. Die argument wat hier ter sake is, behels dat dit juis die ingrypende en omvattende 
Aspekte van 'n Christelike perspektief op fasette van die Geskiedwelenskap ...

aard van verandering in Suid-Afrika is wat opnuut bekende vraagstukke en kritiek op die voorgrond gebring het en wat vereis dat die Christenhistorikus (in wye sin) ' $\mathrm{n}$ herevaluering moet mak van verskeie fasette van die Geskiedsbeoefening om weer eens te poog om aan die ideologiese en tydgebonde valstrikke van die verlede te ontkom.

Van die heersende tendense met betrekking tot Geskiedsbeoefening in SuidAfrika wentel onder andere om die volgende aspekte:

* Beweerde eensydige vertolkings van die verlede (vgl. onder meer Anon., 1990; Horn, 1986; Van Jaarsveld, 1990a en 1990b).

* Kurrikula op sekondêre en tersiêre vlak wat, volgens sommige mense, blanksentries neig (Van Jaarsveld, 1990:3; De Klerk, 1994:53).

* Die bevraagtekening in onderwyskringe van die doel en waarde van Geskiedenis as outonome vak op grond van die relatiwiteit verbonde aan die vertolking van die verlede (Rüsen, 1991:1-6).

Bovermelde aspekte is bloot 'n refleksie van 'n dieperliggende en omvangryker vraagstuk, naamlik dat die Suid-Afrikaanse Geskiedsbeoefening oor 'n lang tydperk in 'n mindere of meerdere mate diensbaar was (bewustelik en/of onbewustelik) aan bepaalde ideologieë (Rapport, 1993-09-23; 1995-04-23 en 1995-04-30). Om hierdie ideologiese greep af te skud en 'n sogenaamde betroubare en gebalanseerde omvattende geskiedenis van Suid-Afrika daar te stel, beteken nie bloot dat enkele byvoegings tot die bestaande historiografie gemaak moet word nie, maar dat 'n fundamentele herinterpretasie van historiese gebeure gemaak sal moet word. "Herinterpretasie" en 'n "omvattender en vollediger" Suid-Afrikaanse geskiedenis is egter ook konsepte wat in bepaalde kringe vertolk word/vertolk kan word as die ideologies eksklusiewe "omdop" van historiese feite en gebeure wat nie gaan neerkom op meerdere korrektheid en volledigheid nie maar op 'n nuwe eensydigheid en 'n leuen. Die resentste nommer van die Jaarboek van die Suid-Afrikaanse Kommunikasıediens ten opsigte van die SuidAfrikaanse geskiedenis reflekteer die strekking van hierdie argument (Engelbrecht, 1995:9). Inherent aan dié herinterpretasie lê dus opnuut die vraagstuk van 'n ander maar nuwe ideologiese gebondenheid opgesluit. Die vraagstuk vir die Christenhistorikus wentel nie in die eerste plek rondom die meriete van 'n korrekter en vollediger Suid-Afrikaanse geskiedskrywing nie, maar om die ideologiese dimensies daarvan. Idcologiese raamwerke maak nie net ' $n$ aanslag op sogenaande (objektiewe?) feitelike besonderhede nie maar fokus baie sterk, via die kognitief-normatiewe veronderstellings daarvan, op die hervertolking van historiese gebeure. Hierbenewens is ideologieë denkstrukture en -ingesteldhede wat by uitstek gerig is op die voorwetenskaplike uitgangspunte onderliggend aan wetenskaplike navorsing en onderrig (Baradat, 1991:2-8; Esterhuyse, 1987:313-314). 
Dat die bekende gevaar van ideologiese dienstigheid met betrekking tot die Geskiedsbeoefening nie iets van die verlede is nie maar steeds sy invloed kan laat geld, is af te lees uit enkele fasette van die nuwe Suid-Afrika wat tot stand gekom het en nog verder gaan ontplooi:

* Die plek en die interpretasie van die "struggle" - ingeslote die kernmomente daarvan soos politieke leiers cum helde, die Black Consciousness Movement (Steve Biko), die gewapende stryd en die morele regverdiging van geweld, strukturele geweld en onderdrukking, en die plek en rol van bevrydingsteologie.

* Politieke pogings on die minderwaardigheid wat apartheid werklik en/of vermoedelik geskep het, te elimineer en die teendeel daarvan te laat bevestig.

* Die interpretasie van besonderhede deur die Waarheids- en Versoeningskommissie

* Die inkleding van rekonsiliasie binne ' $n$ historiese raamwerk en 'n bepaalde politieke konteks

* Die strukturering en inkleding van nasionale eenheid (nasiebou) in die lig van die historiese raamwerk waarbinne dit gedoen moet word.

* Die onvattende herdefiniëring van die grondfunksies van navorsings- en onderriginstellings en die rol wat dit binne nasionale-eenheidsprogramme kan en sal moet speel.

Die totstandkoming van die sekulêre Suid-Afrikaanse staat plaas Christelike waardes en dus lewens- en wêreldbeskoulike uitgangspunte toenemend onder druk. Die eens bykans algemeen "verskansde en bevoorregte" posisie wat Christelike waardes in formele sin geniet het, bestaan nie meer nie. Trouens, die Handves van Menseregte het (benewens die noodsaaklike) die deur ook geopen vir 'n hele stel ander nie-Christelike waardes wat amptelik gangbaar geword en/of toelaatbaar gemaak is en/of vergemaklik is. Hierdie waardes en tendense sluit onder andere die volgende in

* Die Herstrukturering- en Ontwikkelingsprogram (HOP) wat naas die onaanvegbare noodsaaklike en verdienstelike oogmerke daarvan ook neig om ' $n$ omvattende ideologiese raamwerk te word

* Die opkoms van die sogenaande stille revolusie met betrekking tot "alternatiewe" perspektiewe op fundamentele waardes (hinne die kader van die reformatoriese Christendom).

* Mens, samelewing, bestemming, kennis (wetenskap) en skool op amptelike en op algemene samelewingsvlak 
Aspekte van 'n Christelike perspektief op fasette van die Geskiedwetenskap...

$\mathrm{Al}$ hierdie aspekte impliseer 'n wye stel waardekonfrontasies met onder andere die New Age1-beweging, utopisme, verwêreldliking en modernisme (Wiese, 1995:12-13). Die pogings van Jan Alleman - hoewel nie altyd eksplisiet nie om antwoorde op hierdie en ander verbandhoudende vrae en onsekerhede te soek, demonstreer reeds die wesenlike teenwoordigheid en 'n totaal nuwe en ander lewensraamwerk waarbinne die Christen hom in Suid-Afrika bevind.

Dié tendense is tans die onderwerp van bespreking binne die raamwerk van 'n onstabiele landsituasie ${ }^{2}$ waar haat, onreg en 'n eis vir sigbare demokrasie nie vreemd in die woordeskat van Suid-Afrikaners opval nie. Ook is hierdie tendense uiteraard van die grootste belang vir die Christen-historikus van wie verwag word om nie 'n slagoffer van die tydsgees te wees nie.

Binne hierdie gegewe is die Potchefstroomse Universiteit vir Christelike Hoër Onderwys (PUCHO) tans die enigste universiteit in Suid-Afrika wat as tersiêre opleidingsinstansie die Christelike karakter in sy wetenskapsbeoefening openlik onderskryf (Ouweneel, 1993:323; Botha, 1995:121-122). Teenswoordig, en onvermydelik so, is die PUCHO egter ook op die kruispad met betrekking tot sy toekomstige posisie en karakter binne die raamwerk van die nuwe grondwetlike bestel in Suid-Afrika (Botha, 1995:122, 134-140; PUCHO-Raad Nuusbrief, 1994:1-6; Anon., 1991:10-12). Dus: die Universiteit as sodanig en daarmee saam alle dissiplines is in die een of ander opsig onderhewig aan genoemde veranderings en nuwe eise wat gestel word.

Teen dié agtergrond ontstaan die vraag hoedanig 'n Christelike perspektief op die Geskiedswetenskap historici en Geskiedenisonderwysers in 'n veranderende Suid-Afrika in staat kan stel om die verlede met groter omsigtigheid en prinsipiële verantwoordelikheid te belig en te hanteer sodat die waarheid nie geweld aangedoen word en hulle as wetenskaplikes nie diensbaar word aan ander gode of nuwe ideologieë nie.

\section{Doelstellings, metode en ondersoekterrein}

Die teoretiese aanname wat gemaak word, behels dat 'n gereformeerde Cliristelike perspektief op die Geskiedswetenskap in beginsel die waardegrondslag en nonmatiewe basis bied om, binne die perke van die menslike gebrokenheid, met eerlikheid die waarheid na te streef en om die interpretasie van

1 Dic New Age-bewcging word gesicn as 'n altcrnaticwe rigting binne dic godsdıens waarin Calvinisme as verstandsgodsdiens getipecr word en verder getipeer word as dat dit nic bevredigende antwoorde op lewensvrac het nic Vergelyk Wiesc (1995) en Van Nickerk en Meier (1994:69-84).

2 Vergelyk onder mecr met Rapport, 5 September 1993 asook 23 en 30 April 1995 
Elize S. van Eeden \& C.J. Coetzee

die geskiedenis binne die Christelike perspektief van skepping, sondeval en herskepping te bestudeer en te doseer in plaas daarvan oin dit slaaf van nuwe eensydige of reduksionistiese ideologiee te maak of te laat verword.

Die hoofdoel is om aan die hand van 'n uiteensetting van enkele belangrike Christelike perspektiewe aangaande die werklikheid, die mens, samelewing, geskiedenis en kennis, die geldigheid van die teoretiese stelling aan te toon. Ter illustrasie van verideologiseerde Geskiedsbeoefening word enkele strominge benadruk - met die insluiting van vaderlandse geskiedenis. Laastens word die gestelde Christelike nornatiewe raamwerk in verband gebring met 'n Christelike geskiedsbeoefening ten aansien van 'n veranderende Suid-Afrika.

Hierdie bydrae fokus op fasette van 'n Christelike geskiedsbeoefening en konsentreer hoofsaaklik op enkele voorwetenskaplike benaderings ten opsigte van Geskiedsbeoefening.

\section{Enkele Bybelse gesigspunte op 'n Christelike geskiedsbeoefening}

Die Cliristelike geloof is een van die verskeidenheid gelowe wat in Suid-Afrika aangetref word (Van der Walt, 1994:51-53). Met Christelike wetenskapsbeoefening, wat onafskeidbaar binne die kader van hierdie geloof val, word nie noodwendig veronderstel dat die metodiek van dié benadering in alle opsigte verskil van die algemene navorsingsmetodiek - en veral tegnieke en standaardnavorsingsprosedures van enige ander dissipline in die sosiale wetenskappe nie Wat wel hier ter sprake is, is die aanname dat 'n Christelike wetenskaplike Geskiedsbeoefening in beginsel en noodwendig verskil ten opsigte van veral voorwetenskaplike aannames. Op grond van hierdie voorwetenskaplike aannames kan sodanige geskiedsbeoefening - sover dit die evaluering en interpretasie van historiese gebeure en ook die omgaan met besonderhede betref - 'n verskil maak. Dit gaan dus eerder oor hoe die navorser sy Christelike lewens- en wêreldbeskouing binne die navorsingsterrein en -wetenskapsaktiwiteit inklee. 'n Oortuigde Christenwetenskaplike maak erns met hierdie lewens- en wêreldbeskouing juis as gevolg van sy bewustheid van die gebroke wêreld van voorveronderstellings en die verskeidenheid waarvan hy/sy deel vorn (Ouweneel, 1993:336; Botha, 1995:121-148). Voorveronderstellings en paradigmas word nie eksklusief deur sosiale, ekonomiese, estetiese, perseptiewe en sensitiewe faktore bepaal nie, maar is grondliggend, religieus en wysgerig van aard (Ouweneel, 1993:336).

In 'n geskiedbeskouing gebaseer op 'n Christelike perspektief word die Woord gesien as die besondere openbaring van God in die lig waarvan die werklikheid, en dus ook die geskiedenis, benader behoort te word. Dit veronderstel nie dat die Bybel in dié proses as wetenskaplike handboek of as ' $n$ historiese bron moet 
Aspekte vain 'n Christelike perspektief op faselte van die Geskiedwetenskap ...

dien, of dat Bybelse gegewens die plek van wetenskaplik gefundeerde gegewens moet inneem nie.

Enige Christenwetenskaplike (en in gevalle ook ander) is bewus van die beperkinge van die wetenskap en van die menslike verstand. Sogenaamde "suiwer" rasionele wetenskapsvrae aangaande byvoorbeeld die oorsprong, toekoms en sin van die werklikheid kan geen finale wetenskaplik verantwoordbare verklarings oplewer nie. Dit beteken egter nie dat die soeke na wetenskaplike verklarings en perspektiewe met betrekking tot mens, tyd en gebeure totaal opsygeskuif moet word nie. Juis vanuit 'n Bybelse perspektief gesien, het die mens 'n kultuur- en beheersingstaak en is hy geroep om God juis met hart en verstand lief te hê en te verheerlik.

'n Vername aspek van die Christenhistorikus se werklikheidsbeskouing en van sy taak as wetenskaplik-soekende kenner van verskynsels en objekte sal byvoorbeeld wees of hy die verwoestende uitwerking van die sonde op aarde en in mense herken en erken, aangesien dit 'n bepaalde invloed op sy taak sal hê. 'n Christelike perspektief op geskiedsbeoefening gaan van die vertrekpunt uit dat God as die middelpunt van die geskiedenis beskou word (Hofman, 1990:18). Vir hom geld die beskouing van Openbaring 4:11 waar God as die Skepper van alles beskryf word en van Romeine 11:36 wat lui: "... uit Hom en deur Hom en tot Hom is alle dinge".

God se bemoeienis met die mens en aarde word uit Genesis 1:1 bekend - dit stel dat God in die begin hemel en aarde geskep het, en alles goed (vgl. vers 31) gemaak het. Die mens se sondigheid, kort na die Skeppingsdade van God, openbaar enersyds die verwoestende gevolge (die vloek) daarvan op mens en op skepping en andersyds juis God se liefde (1 Johannes 4:7-9, 20). God se liefde word geopenbaar deurdat Hy sy Seun aan menswording en 'n kruisdood onderwerp het om die mens van sy sonde te heel (vgl. Kolossense 1:13-20) en om hierdie aardse bedeling te bring tot herskepping. Die Christenhistorikus beskou ook die wederkoms van Christus, soos deur die Woord uitgewys in Openbaring 21 , as die eindpunt van die sonde-vervalle aardse bedeling (vgl. De Klerk, 1981:17-19). In hierdie sin is God ook die voleinder van sy raadsplan en van die geskiedenis van die mens en van God se ewige verlossingsplan. Die Godsopenbaring, wat in wese 'n bekendmaking is van die verlossingsboodskap, illustreer by oormaat hoe God die geskiedenis van die mens rig, gebruik en lei.

Uit hoofde van die doel en aard van die geopenbaarde Woord van God moet 'n prinsipiële Christelike beskouing van die geskiedenis nie gesien word as 'n aprioriese omvattende wetenskaplike teoretiese sisteem waarbinne geskiedenisse georden moet word nie. Gods Woord bevat slegs enkele basiese opvattinge oor die begin, verloop en einde van alles (De Klerk, 1994:14-15 en De Klerk, 1981:153). Die Christenhistorikus laat hoin deur die Woord lei om sy 
Elize S. van Eeden \& C.J. Coctzee

werklikheids- en geskiedbeskouing van die wêreld te vorm, en daarmee ook die ingesteldheid en uitgangspunt ten opsigte van sy wetenskaplike ondersoek (De Klerk, 1994:14).

J. Schaeffer argumenteer op sy beurt dat die Christenhistorikus as't ware "het stof van de feiten afblazen en laten sien: zo werkt de mens - maar ook bij het licht van Gods Woord" (Schaeffer, 1990:9). Vergelyk die beskouing van Schaeffer na aanleiding van 2 Petrus 1:3, 5-7 waar 'n oproep gedoen word dat die mens sy deugde en kennis met verantwoordelikheid sal aanwend. Ook veronderstel Psalm 36:10 dat dit in die Lig van God se Woord moet geskied: "In u Lig sien ons die Lig". Christenhistorici behoort dus deur wetenskaplike ondersoek van alle beskikbare bronne kennis van die geskiedenis te bekom en kan dan eers, deur 'n sintese van hierdie kennis, 'n geheelbeeld vorm. Hierdie sintese en ondersoek berus egter op voorwetenskaplike prinsipiële aannames en perspektiewe insake die mens en sy geskiedenis.

Wanneer historici 'n Christelike perspektief voorhou, beteken dit steeds nie dat hulle almal presies dieselfde wetenskaplike beeld van die geskiedenis sal gee nie. Persoonlikheidseienskappe, verskille in navorsingsmetodiek, tyds- en omgewingsfaktore sowel as nuwe ontwikkelinge, kan steeds die Christen se lewensbeskoulike interpretasie van vroeëre gebeure beinvloed (Howard Rienstra, 1977:11, 16) en inwerk op die wetenskaplike bevinding. Fundamenteel is die voorwetenskaplike aannames en prinsipiële perspektiewe van die Christen op die kosmos, mens, waardes, samelewing, gebeure ensovoorts egter dieselfde en dien hulle as norm waarop teruggeval kan en behoort te word. 'n Christelike perspektief dwing die wetenskaplike tot nederigheid en erkentlikheid ten aansien van die magtige dade van God - en veral teenoor die universele sondige aard van die mens. In dié sin bied 'n Christelike perspektief op die historiese geen ruinte vir selfregverdiging, selfverheffing, menslike ideologiese dienstigheid en wraak nie. Nog minder word ruimte gebied vir 'n vermyding van kritiek op sy eie gebrokenheid, die negatiewe en verkeerde in sy eie vakverband, lewe en optrede. Insgelyks mag die Christennavorser hom nie afsluit van die veelheid van perspektiewe op die historiese ten aansien van 'n beperkte en eng eie nasionalistiese voorkeur nie

\section{Christelike geskiedskrywing: internasionale strominge}

Dat selfs en veral Christelike benaderings tot die geskiedenis hoogs feilbaar was en kan wees, staan vas. Uit die onderstaande voorbeelde van enkele strominge blyk hierdie immerteenwoordige gevaar en noop dit die Christenwetenskaplike om telkens sy fundamentele Christelike vooronderstellings te herondersoek in die lig van die Skrif. 
Aspekte van 'n Christelike perspektief op fasette van die Geskiectwetenskap ...

'n Kenmerk van Christelike denke in die Griekse en Romeinse beskawingstydperk en tydens die Middeleeue was 'n poging om Christelike oortuigings met klassieke heidense (v.C.) wysgerige beskouinge te versoen binne die raamwerk van wetenskapsbeoefening - die sogenaamde sintese. Denkers het geglo dat geskiedenis 'n voortdurende kringloop is, naamlik dat alles wat gebeur het, weer sal herhaal (dus ' $n$ geslote en sikliese werklikheidsbeskouing sonder ware verlossingshoop). Binne die sikliese geskiedsbeskouing kon lesse uit die volksverlede gehaal word ter normatiewe bepaling van optrede in die hede en / of verklarings daarvoor. In wese veronderstel dié siening 'n partikularistiese samelewingsbeskouing (De Klerk, 1973:3). Die Middeleeuse geskiedskrywing word ook gekenmerk deur kronieke, lewensbeskrywings van heiliges en van voorbeeldige persone wat as eksemplare gedien het vir en van van 'n deugsame Christelike lewenswandel (Niebuhr, s.j.:223-276; De Klerk, 1981:12, 118). Reeds vanaf die sestiende eeu het 'n sekularisasieproses in die geskiedbeskouing ingetree. Hiervolgens het nie meer God se dade met die mens nie, maar die mens se vooruitgang deur eie prestasies, en die mens as voorbedagte "skrywer" en "determineerder" van sy geskiedenis (en nie meer God wat die geskiedenis "skryf" en beheer nie) op die voorgrond getree (De Klerk, 1994:8). Hierdie benadering is op voorwetenskaplike vlak gekenmerk deur die proklamering van die selfvoldane en outonome mens, die volledige kenner van die werklikheid en die gepaardgaande geloof in die sekerheid van sy (wetenskaplike) kennis. Die sin van hierdie selfdeterminerende mens se geskiedsbeskouing is enersyds gesoek in sy eie vermoe om hom te "verlos" van die verlede en andersyds is dit gesoek in die skepping van die nuwe (ideologiese) utopie. Op hierdie wyse tree dus 'n bepaalde kenteorie en 'n dominante politieksentriese beskouing na vore - 'n beskouing waarin regerings, owerhede, magte en persone 'n beslissende rol speel. Hierdie beskouing staan lynreg teenoor die teosentriese benadering of die siening van Godsheerskappy.

Gedurende die periode van die Hervorming het sowel die Protestante as die Katolieke hulle tot geskiedskrywing gewend om elk sy eie benadering tot die lewe te verdedig (Milbum, 1954:1-34; Harris, 1964:270-288). In vele opsigte blyk dié benadering tot die geskiedenis egter soortgelyk te wees aan dié in die Middeleeue maar met die belangrike onderskeid dat lewensbeskoulike verskille na vore gekom het en enersyds gefokus het op die teosentriese benadering en andersyds op die uitlewing daarvan in kerkverband (vgl. Kapp \& Moll, 1988:288291; Van Wijk \& Spies, 1985:287-297).

Na die Hervorming het die agtiende-eeuse Verligtingstydperk gevolg wat 'n groot invloed gehad het op geskiedskrywing as sodanig. Geskiedskrywing is onder meer gebruik om bepaalde filosofiese idees te illustreer en te propageer. John McManners verwys daarna as high politics and underlying sentiments (McManners, 1992:239). Hieronder tel die Verligtingsdenkers se gedagte van die 
Elize S. van Eeden \& C.J. Coetzee

onbegrensde volınaaktheid van die mens en sy denkvermoëns. Hulle het ook probeer aantoon dat die mensheid in die loop van die geskiedenis steeds verder in die rigting van volmakktheid beweeg het - per se 'n aprioriese opvatting en konklusie.

Oor die geheel gesien, was en is die sogenaamde Christelik-wetenskaplike benaderings van bostaande perspektiewe in die onderskeie tydperke onder verdenking: die fundamentele beginsels van mensgebrokenheid, wetenskapsbegrensdheid, verantwoordbaarheid, werklikheidsdiversiteit en eenheid word nie in hierdie periodes weerspieël nie. Dié sikliese geskiedsbeskouing verhef historiese gebeure en tendense tot norm en vang die mens vas binne die greep van die ideologie van tradisie. In 'n sekere sin word elke sogenaamde "herhaalde gebeure" 'n selfvervullende profesie en 'n herversterking van 'n ideologiese aanname. Die uniliniêre eksemplariese progressie in die geskiedenis kom egter ook nie los van 'n geskiedsbeskouing waarin die mens (die eksemplare) die norm word nie. So 'n geskiedsbeskouing skep slegs die skyn van ware Christelike perspektief op die geskiedenis waarin God sentraal staan.

Eers vanaf die negentiende eeu is deels weggebreek van dié eksemplariese opvatting. Geskiedenis is toe gesien as 'n versameling los gebeure wat as voorbeelde vir optrede in die hede kon dien, maar nie as sodanig algemeen só gehanteer is nie, byvoorbeeld die "objektiewe" bydrae van Leopold von Ranke. Die besondere leiding van God is soms in werke aangetoon, en die geskiedenis is as 'n middel beskou om die wil van God beter te leer ken (Matthew, 1954:142$143,166,414,515){ }^{3}$ Andersins is ook ' $n$ benadering gevolg waardeur die Woord diensbaar gemaak is ter regverdiging van spesifieke regerings, owerhede en magte en hulle handelinge asook die regverdiging van die kwaliteit van bepaalde kulture. Hierbenewens is die Woord van God ook misbruik ter regverdiging van die omverwerping van sodanige owerhede en ter negatiewe evaluering van bepaalde kulture. Wesenlik het dit dus neergekom op eie-belang bo algemene belang met in gepaardgaande verwêreldliking as uitgangspunt (Van Leeuwen, 1966:355-374; De Klerk, 1981:12, 87, 89, 120; Van der Vyver, 1976:130). Bovernelde benadering onderstreep 'n fundamentele aangeleentheid vir die Christenhistorikus, naamlik dat die hermeneuse van die Skrif ten aansien van die prinsipiële eise van God vir 'n ware Christelike benadering tot die wetenskap baie maklik so verdraai kan word dat die mens steeds weer homself in die sentrum plaas

3 Vergelyk byvoorbecld met dic moraliserende geskiedwerke in diê ecu soos byvoorbecld dié van Lord Acton en F.C. Schlosser 
Aspekte van 'n Christelike perspektief op fasetle van die Geskiedwetenskap ...

Vir die historikus wat 'n Christelike perspektief op die Geskiedwetenskap toepas, is dié benadering waarin die Skrif aangewend word na gelang van menslike voorkeure met betrekking tot 'n diversiteit van kulture en owerhede en stelsels ook nie aanvaarbaar nie. Die onaanvaarbaarheid is daarin geleë dat dit vanweë die eensydigheid en die reduksionisme daarvan steeds nie konformeer aan die Bybelse norm van verskeidenheid-in-eenheid nie en ook nie 'n getroue weerspieëling is van die werklikheid (die hier en nou) nie. Tweedens word juis die totaliteitsdimensie met betrekking tot die verlede-inhoud as 'n noodsaaklike komponent van 'n getrouer werklikheidsbeskouing in die onderrig- en navorsingsituasie willekeurig genegeer. Die Christenhistorikus aanvaar juis die beginsel van skeppingsverskeidenheid-in-eenheid en beskou juis samelewings en kulture in eie reg.

Die negentiende-eeuse benadering is in die twintigste eeu voortgesit. Bydraes tot die Christelik-Calvinistiese denke oor die geskiedenis is onder andere gelewer te midde van ander kontemporêre en dominante tydstrominge soos die strukturalisme, die Marxisme en die eksistensialisme (Harris, 1964:287-288; Niebuhr, s.j.:240-242).

In dié verband is in 1965 in Engeland byvoorbeeld 'n studiegroep gestig wat gefokus het op Christenskap en Geskiedenis. Hierdie studiegroep het gefunksioneer as deel van die Universities and Colleges Christian Fellowship. Die studiegroep het dit ten doel gehad om die Christelike geloof met betrekking tot die Geskiedenis as studieterrein onder studente te beklemtoon. Soos die studiegroep, beleef Christenhistorici in Engeland in die hedendaagse samelewing etlike probleme wat die uitlewing van hulle Christelike geloofsperspektief op wetenskapsbeoefening versper. Hieronder tel die kommersiële uitbuiting van die verlede deur die media - soos byvoorbeeld die radio, beeldradio, kunsuitvoerings en toerisme. Regerings, met spesifieke verwysing in die teks na die Britse regering, word beskuldig van manipulasie van Geskiedenisonderwys aan skole (Wolfe, 1990:2-3). Laasgenoemde is 'n aspek wat tans in Suid-Afrika 'n bron van kommer is/kan wees.

Historici soos onder meer H. Butterfield, R.G. Collingwood en M.C. Smit het daartoe meegehelp om die Christelike beskouing, naamlik dat alle mense voor God gelyk is en geen volk of individu belangriker as 'n ander is nie, te bevorder. Daarmee is gepoog om weg te beweeg van 'n partikularistiese geskiedbeskouing en 'n beklemtoning van die belangrikheid om in die rigting van groter objektiwiteit te werk (De Klerk, 1981:87). Hieroor sê Howard Rienstra:

Christians are neither better scholars nor more objective scholars, necessarily. They may be, and the argument ... is that they can and should make claims to being objective and good scholars ... to give more precise 
Elize S. van Eeden \& C.J. Coetzee

meaning to our common commitment to the compatibility and integralness of Fides et Historia (Howard Rienstra, 1977:7-25).

\section{Vaderlandse geskiedenis binne die raamwerk van Geskied- wetenskap in Christelike perspektief}

Suid-Afrikaanse historici, onder andere, laat blyk dat die geskiedenis van SuidAfrika al vanuit 'n wye verskeidenheid paradigmas benader en beskryf is. Hieronder tel geskiedskrywing vanuit 'n konserwatiewe (HAT, 1988:599), 'n liberalistiese, ${ }^{4}$ 'n neo-liberalistiese en 'n neo-Marxistiese 5 benadering. Wat die Christelike benaderings in die verband betref, is die kerkhistorikus, R.M. Britz, byvoorbeeld van oordeel dat die begrip Calvinisme ${ }^{6}$ gedurende die tweede helfte van die negentiende eel in historiesgerigte publikasies begin verskyn het. Volgens Britz verwys die begrip Calvinisme na die sogenaamde voorwetenskaplike Afrikaanse geskiedskrywing van veral skrywers van Hollandse afkoms wat as tipiese voorbeelde voorgehou word, onder meer Hofmeyr (De Afrikaner-Boer en de Jameson-inval), Du Plessis (Jit de geschiedenis van de Zuid-Afrikaansche Republiek) sowel as F. Lion-Cachet (De worstelstrijd der Transvalers)

Tipiese kenmerke van hierdie werke is die aksentuering van die nasionalistiese motief (gebaseer op die negentiende-eeuse idealisme) en die aksentuering van die religieuse (Christelik-Calvinistiese) motief. Nadat die Afrikaanse geskiedskrywing teen 1920 'n professionele karakter verkry het, is die fokus van Calvinisme as hermeneuties en semanties vertolk. Dié uitgangspunt, tesame met die stigting van die Kristelik-Nasionale Bond van Kalviniste in Suid-Afrika, word beskou as die dryfivere wat ' $n$ paradigma voorsien het vir etlike historici (Britz, 1992:36-37).

Uiteraard skep die paradigmatiese verskeidenheid vertolkings van die verlede vir die hedendaagse Christenhistorikus 'n probleem, aangesien 'n neiging bestaan om "sondebokke"7 in die verlede te soek (Van Jaarsveld, 1984:1-25, 72-73).

4 'n Benadering waarin 'n vrysinnigheid met betrekking tot hervorming op "n wye verskeidenheid terreinc, onder meer in dic godsdiens en politick bemerk word

5 'n Hersicne benadering van revolusionere sosialisme soos aanvanklik verkondig deur Karl Marx. Kyk ook K Smith (1988:155-172).

6 Ter verwysing na dic recks Die ontwikkeling van die politieke denke van die Afrikaner Vergelyk ook met Britz (1992:36-37)

$7 \quad$ Figuurlik gesproke is dit icmand wat vir alles dic skuld kry 
Aspekte van 'n Christelike perspektief op fasette van die Geskiedwetenskap

Partikularisme eerder as sekularisme of verwêreldliking vind sy weg in die vertolking van die Suid-Afrikaanse verlede. Binne hierdie benadering het die klem geval op Christelike nasionalisme 8 wat kenmerkend van die SuidAfrikaanse geskiedenis in dié tyd was. Die benadering het ook "bedmaats" onder historici "gewerf" (Smith, 1988:88, 184).

Enkele historici, waaronder G.D. Scholtz (1977), P. de Klerk (1973; 1994), P.S. Dreyer (1974) en F.A. van Jaarsveld (1964), ${ }^{9}$ het sydelings oor die beoefening van Christelike Geskiedwetenskap besin en oor die wyse waarop universele geskiedskrywing binne die raamwerk van 'n Christelike beskouing kan geskied. Hieroor skryf P. de Klerk (1994:15) onder meer dat

... ten spyte van al die faktore wat die historikus se interpretasie beïnvloed, ondersoek historici almal dieselfde werklikheid en gebruik hulle metodes wat in 'n hoë mate ooreenstem. Daarom kan daar te midde van groot verskille 'n groot mate van konsensus tussen historici oor hul beeld van die wêreldgeskiedenis bereik word, veral wanneer hulle gemeenskaplike uitgangspunte het, maar ook wanneer hulle van verskillende beskouinge uitgaan ... ek meen dat 'n Christelike geskiedbeskouing dit vir die historikus ... moontlik maak om 'n geheelbeeld van die wêreld te vorm.

Geen skrywers het die verskeidenheid bestaande vertolkings ten opsigte van die Suid-Afrikaanse vaderland al na behore in 'n Christelike lig geëvalueer of omvattend bevraagteken nie. P. de Klerk het hom wel onlangs deels hieroor uitgespreek (De Klerk, 1994:53-68). Alhoewel dit essensieel belangrik is om geskiedbeoefening in 'n Christelike lewensperspektief te stel, behoort daar egter gewaak te word om in die beoordeling van die historiese werke historici lukraak aan voorveronderstellings te koppel sonder om dit behoorlik wetenskaplik te bevestig.

'n Tipiese voorbeeld is Britz se verwysing na die werk van C.F.J. Muller (red.), 500 Jaar Suid-Afrikaanse geskiedenis, waarin Muller in die samevatting van Calvinisme klaarblyklik gesê het (direk uit Britz aangehaal) dat:

Geinspireer deur 'n Calvinistiese godsvertroue het die Afrikaners hulle geroepe begin voel om as selfstandige volk die taak van die uitdra van die Westerse Christelike beskouing [- op die patroon soos hulle gesien het] in Afrika aan te durf (Britz, 1992:37-38).

8 Vaderlandsliefde wat 'n oorecnstemming veronderstel met dic lecr van Christus, spesifick gefokus op dic tradisies en idealc van in bepaalde kultuurgrocp/volk.

$9 \quad$ Vgl ook Van Jaarsveld (1984) 
Deur Britz se bewustelike weglating van die gedeelte in hakies aangedui, kom dit heel anders voor as wat Muller dit in die konteks bedoel het. Myns insiens is dit 'n veralgemening en 'n vereenvoudiging - vooroordele waarteen Britz die SuidAfrikaanse historici so terloops waarsku. Dié tipe vertolkings kom egter voor en is skerp onder die soeklig (Van Jaarsveld, 1984:72, 139; Botha, 1995:121-147; Van der Walt, 1994:63-66).

\section{Vertolkingsaspekte wat die Christenhistorikus en Christen- geskiedenisonderwyser raak}

Wanneer 'n Christelike perspektief op 'n veranderende Suid-Afrika toegepas word, moet die historikus en onderwyser onder andere die volgende aspekte in aanımerking neem: verantwoordbare navorsing, kurrikulering, onderrig en inhoudelike vertolking.

Beroepsbeoefening deur die historikus behels in wese navorsing, publikasie en onderrig (dosering) en dié van die Geskiedenisonderwyser hoofsaaklik onderrig. In albei se beroepsuitlewing is lewensbeskouing, mensbeskouing, samelewingsbeskouing, kenteorie en voorveronderstellings oor die algemeen in 'n bepaalde raamwerk of denkwyse ingebed. Sodanige raamwerk bring uiteraard mee dat vertolkings van byvoorbeeld die Suid-Afrikaanse verlede nie dieselfde inkleding of invalshoek sal hê nie. Die verskeidenheid vertolkingsinterpretasies kan sekerlik beskou word as aanvaarbaar binne die raamwerk van 'n Christelike benadering mits 'n oordeelkundige omgang vanuit 'n eg Christelike lewensbeskoulike raamwerk - (heenwysing na Ouweneel) met die verlede ten aansien van kurrikulering, navorsing, publikasie en onderrig ter sprake is.

Tans is dit sonder twyfel waar dat 'n onoordeelkundige en/of onverantwoordelike omgang met die verlede meegewerk het dat die Suid-Afrikaanse verlede as omstrede gesien word. Hierdie omstredenheid geld eweneens vir die sogenaamde eensydige skoolkurrikula en laandboeke sowel as vir die kontroversiële aard van vertolkings van sekere historiese gebeure wat dikwels neerslag vind in ondeurdagte/ondeurgronde uitsprake. Hierdie tipe uitsprake is uiteraard gegrond op die een of ander voorveronderstelling en is ' 1 tendens wat ter plaatse en ook wêreldwyd in die historiografie neerslag gevind het.

Alhoewel bovermelde ondeurdagte omgang met betrekking tot die verlede nooit goedgepraat kan word nie, moet daar begrip wees vir die dikwels emosionele standpunte en optredes, komende van kultuurgroepe, veral tydens en kort na ingrypende historiese gebeure. Vergelyk byvoorbeeld die referaat van Van der Walt (1994:63-65) waarin die partikuliere eienskappe van 'n kultuur, wat diep gewortel is in die religieuse grondmotief, uitgewys en toegelig word. 'n Tipiese voorbeeld hiervan is die ontstaan van die Soka (iakka of die Waardeskeppende Gemeenskap in Japan wat net voor die beëindiging van die Tweede Wêreldoorlog 
Aspekte van 'n Christelike perspektief op fasette van die Geskiedwetenskap

gestig is as emosionele uitvloeisel van die ingrypende ekonomiese gebrek en hongersnood. Die Soka (jakkai moes dien as onderdak vir aspekte van godsdiensbeoefening, byvoorbeeld geloofsgenesing, evangelisme, Bybeluitleg en so meer met die hoop dat dit materiele bloei vir gelowiges sou bring. Uit die Soka Gakkai is die Komeito-party gedurende die sestigerjare gestig (McNelly, 1993:277)

Op Suid-Afrikaanse bodem sou dieselfde gesê kon word van die sogenaamde Black Theology (as verlengstuk van die Amerikaanse Swart Teologie en die Bevrydingsteologie in Latyns-Amerika) soos vanuit die pen van dr. A. Boesak in sy Farewell to innocence. A social ethical study of Black Theology and Black Power waarin hy eksplisiet die volgende uitspraak maak:

This book was born out of the black experience in South Africa. Out of anguish and deep concern; out of the inevitability of commitment; out of anger, and a fragile, but living hope. Out of an inexplicable joy through faith in Jesus the Messiah, whose refusal to let go of me has been my liberation (aangehaal deur Van der Merwe, 1977:12, vgl. ook met Boesak, c.a. 1975:29).

Verder aan in die teks sê dr. Boesak:

Blacks have used Christianity not as it was delivered to them by segregated white churches, but as its truth was authenticated to them in the experience of suffering, to reinforce an ingrained religious temperament and to produce an indigenous religion orientated to freedom and human welfare (aangehaal deur Van der Merwe, 1977:13).

Benewens die Sokka Gakkai en die Swart Teologie, as tipiese voorbeelde van bewegings met emosionele, ingrypende komponente is daar ook nog die 1985 Kairosdokument (Institute for Contextual Theology, 1985:19), vyf jaar later gevolg deur die dokument Violence, the new Kairos (Institute for Contextual Theology, 1990:1-14) en selfs die Afrikaanse Protestantse Kerk wat in 1983 as blanke Afrikaanssprekende kerk afgestig het van die Nederduitse Gereformeerde Kerk as gevolg van onversoenbare prinsipiële uitgangspunte en ideologieë (vgl. byvoorbeeld Die Voortsettingskomitee 1987:5 se art. 1.24-1.26). Hierdie uitgangspunte en ideologiee was gewortel in die politicke emosies van die tyd, die versplintering in blanke partygeledere met die stigting van die Konserwatiewe Party in 1982, gevolg deur die Blanke Referendum in 1983 en die nuwe Konstitusionele bedeling in 1984 . Tydens hierdie gebeure het die blanke in wese van sy jarelange politieke ciendomsreg afstand begin doen (Liebenberg \& Spies, 1993:476-477, 525). Diepgaande studies sal heel waarskynlik nog soortgelyke patrone in Suid-Afrika blootlê. 
Op grond van die Skriftuurlike beginsel van eenheid en verskeidenheid moet die verskeidenheid kulture in Suid-Afrika deur alle kulture in eie reg erken/aanvaar word, sowel as daardie gemeenskaplike aspekte wat 'n menslike gemeenskap as eenheid snoer (vgl. Kol. 3:11 en 1 Kor. 9:20). Die Skrif bepleit geen nivellering van menslike diversiteite nie.

Straks is dit juis nou in 'n veranderende Suid-Afrika nodig vir die Christenhistorikus en die met onderrig gemoeid om paradigmas des te meer te herken in die geskiedskrywing en/of aanbieding, en dit reformerend te hanteer binne die grondliggende raamwerk van 'n Christelike beskouing.

\subsection{Kulturele diversiteit}

In hierdie verband merk Van der Walt op dat "die Christenwetenskaplike hom/haar bewustelik kan laat lei deur die Bybel as Goddelike openbaring, en in die lig daarvan groter perspektief op die werklikheid verkry om so die partikuliere en universele, sowel as die tydelike en die ewige in balans en in perspektief te kan plaas" (Van der Walt, 1995:41-51). 'n Christelike beskouing en benadering is per definisie en openlik religieus bepaal en gerig. Die Christenwetenskaplike en dosent/onderwyser het 'n bepaalde voordeel bo die wetenskaplike wat nie 'n Christelike beskouing vooropstel nie. Hierdie vooropstelling is bloot omdat die Christenwetenskaplike fundamenteel en nonnatief beter in staat behoort te wees om byvoorbeeld kulturele vooroordele, etniese chauvisnisme en verwronge voorveronderstellings prinsipieel te identifiseer en te evalueer om sodoende tot 'n objektief moontlike en sinvoller kenresultaat te kom (kyk byvoorbeeld die redenasie in 5.1).

Binne die raamwerk van die onderwys gaan die vernoë om kulturele diversiteit en/of multikulturaliteit in prinsipiële perspektief te plaas groot uitdagings meebring. Die vennoë tot veral deduktiewe Geskiedenisonderrig, waarin die leerders eie afleidings uit die onderriginhoud moet maak, veronderstel groter inspraak by direkte leerbetrokkenheid, en hou ook voordele in vir die verkryging van 'n getrouer geheelbeeld oor 'n bepaalde saak. Die filosofiese grondslag wat transkulturalistiese onderrig bekleıntoon binne die geskiedenisraamwerk van die Christenhistorikus/-onderwyser, is gebaseer op die feit dat pluraliteit erken en bevorder sal word. Praktiese uitvoering daarvan is veral binne 'n dissipline soos Geskiedenis nodig (vgl. Van der Walt, 1995:48, punte 3 en 4). Stremmende faktore soos kultuurgroep, die persoonlikheid en belangstellings van die historikus sowel as tydsgebondenheid, behoort dus nie meer 'n negatiewe rol te speel in Geskiedenisonderrig en geskiedskrywing nie. Soos Dreyer dit stel, verander die Lig nie die objekte nie, "maar is die aard van die Lig medebepalend vir die indrukke wat die objekte op ons maak, die wyse waarop ons objekte interpreteer en weergee" (Dreyer, 1974:240; Wolters, 1992:73-74). J. Schaeffer se uitspraak vul ook die benadering aan. Hy sê: "een goede omgang met mensen 
Aspekte van 'n Christelike perspektief op fasette van die Geskiedwetenskap

vraagt heel veel liefde en tegelijk heel veel waaksaamheid om te onderscheiden tussen schijn en werkelijkheid, tussen onmacht en onwil, tussen waarheid en leugen" (Schaeffer, 1990:8).

\section{Ten slotte}

'n Onoordeelkundige en ongebalanseerde omgang met feite en woorde in die Geskiedwetenskap en Geskiedenisonderrig kan 'n skeefgetrekte beeld van die verlede skep en tot wanpersepsies aanleiding gee. Inderdaad kan dan gesê word dat die bestaan en koms van God se koninkryk in hierdie land - Suid-Afrika belemmmer word. P.J. Heiberg sê in dié verband dat die "skrywer sy eie woorde ernstig [moet] oordink en sy ryke begaafdheid daadwerklik inspan om die koninkryk van God te laat kom" (Heiberg, s.j.:11; Van der Walt, 1990:41-44). As die Geskiedwetenskap in Suid-Afrika met verantwoordelikheid in die lig van 'n Christelike beskouing beoefen word, kan daar meer ruimte en 'n toegeneentheid wees vir balans en 'n eerlike vertolking van die Suid-Afrikaanse verlede. So 'n vertolking behoort sekerlik veel meer werd te wees vir die SuidAfrika van tans en van die toekoms. Dit geld vir diegene in die onderwyspraktyk, veral vir die historikus en die Geskiedenisonderwyser/-dosent.

\section{K.J. Popma som die verantwoordelikheid van die historikus só op:}

Wie iets van die eeuwige schoonheid der historici leert zien, die sal zijn geloofinzicht tot geen prijs willen missen. Alles sal hij over hebben om dit geloofinzicht te verwerwen en voor niets ter wêreld zal hij het feil hebben. Hij koopt de waarheid en verkoopt ze niet. Hij zal ook den tijd beproeven, opdat zijn Heer hem niet slapende zal vinden (aangehaal deur Van der Vyver, 1976:132).

Per se beteken dit dat Popma veronderstel dat die lewens- en wêreldbeskouing van die Christenhistorikus geloofsinsig inhou en nie net wetlike insig nie. S.S. Banard (1992:1) vul verder aan deur die gelowige Christenonderwyser se lewens- en wêreldbeskouing te identifiseer, as 'n "[p]ositiewe Christelike lewensen wêreldbeskouing, genormeer na die eise van God se Woord [wat] ... duidelik [sal] spreek uit elke gebaar, elke stemtoon, elke blik na die kind, elke uitgesproke woord en elke glimlag".

Dit kan veral vir die onderwyser in Geskiedenis geld, aangesien met soveel menslike inhoud vol gebreke gewerk word.

Negatiwiteit onder historici met betrekking tot die uitleef van 'n Christelike beskouing in dié wetenskap, veral soos bo vereis, is nie vreemd nie. Redes wat vir hierdie negatiwiteit aangevoer word, sluit die volgende in:

* Die onwetenskaplikheid of (wetenskaplike) onbewysbaarheid van die Bybel. 
* Die eie beperktheid en die beperktheid van die wetenskap wat beoefen word. Dit ontlok 'n skeptisistiese of antagonistiese houding.

Alleenlik as die beoefenaars van die Geskiedwetenskap sal besef dat die hart van die evangelie impliseer dat Christus bimne die geskiedenis staan, en nie daarbuite nie, dan sal en behoort Christelik gefundeerde waardes die beoefenaars van die Geskiedenis met meer as menslike gesag en ontsag te beinvloed (Dreyer, 1974:241-245). In 'n Christelike beskouing bepaal God die geskiedenis, "maar nie op so 'n wyse dat hy die mens van sy verantwoordelikheid ontneem nie ..." (Dreyer, 1974:247). Hierdie verantwoordelikheid moet met erns beoefen word in die lig daarvan dat rekenskap gevra en gegee sal moet word in die Hiernamaals.

Ondanks die sonde van die mens laat God 'n nuwe mens in hom opstaan wat die ou mens bestry en deur die leiding van die Gees in die gedurige stryd die oorwinnaar is. Hierdie troos is slegs van toepassing op diegene wat 'n vrees vir die Here het, en in staat gestel word om die $e k$ in totale oorgawe tot God se gebruik te stel (Helberg, 1981:91). Ons moet dus alles as "nuwe" mense in 'n "nuwe" Lig bestudeer. Dit geld ook vir al die kulture wat gesamentlik aan 'n demokratiese bedeling in Suid-Afrika bou.

Sonde kan die opvatting tuisbring dat jou kultuureie die enigste en geregverdigde is (Coetzee, s.j.:7). Inderdaad kan dit daarop neerkom dat God deur een volk vir homself geannekseer word (Helberg, 1981:91). Tans is dit nodig dat historici, en hoofsaaklik dié gemoeid met Geskiedenisonderrig, sal besef dat die nodige perspektief op die Suid-Afrikaanse situasie, soos vroeër beklemtoon is, uiters noodsaaklik is. Daarmee hang saam die besef dat volkskap ondergeskik is aan Christenskap en nie in beginsel daannee in stryd is nie. God moet meer gehoorsaam word as die mens. J.H. Coetzee meen ook dat dit nodig is om korrek nasionaal te wees, aangesien nasionaal-Christelikheid in wese onchristelik is (Coetzee, s.j.7). Eweneens geld dit vir diegene wat op 'n partikularistiesnasionalistiese wyse volkere se bestaan in Suid-Afrika sou bestudeer en doseer.

In die lig van 'n Christelike beskouing met betrekking tot die lewe kan dit nie anders as dat die geskiedwetenskaplike en onderwyser/dosent van Geskiedenis radikaal prinsipieel met sy inhoud sal omgaan nie. In dié opsig het tersiêre en sekondêre inrigtings in Suid-Afrika 'n grootse taak om skoliere/studente op 'n eerbare wyse vir hul lewenstaak te vorm.

Gelowige Suid-Afrikaners het 'n kosbare skat - hul Christenskap. Hierdie skat bied ruimte om die lewensbeskouing met volle oorgawe in 'n Christelike perspektief te beleef en uit te leef. In 'n veranderde tockomstige Suid-Afrika kan dié oorgawe en toewyding aan die Allerhoogste net goeie vnigte dra. Binne die raamwerk van tersiêre en sekondêre instansies, waar die Geskiedwetenskap beoefen word, is dit dringend nodig om die Christelike lewensbeskouing uit te 
Aspekte van 'n Christelike perspektief op fasette van die Geskiectwetenskap ...

leef. Gepas lui die Skrifwoord" "In U Lig sien ons die Lig". Mag dit van alle Christenhistorici, Geskiedenisonderwysers en Suid-Afrikaners waar wees.

\section{Bibliografie}

ANON. 1990. Ons helde Nuwe SA vra nuwe rolmodelle Rapport 4-5, Okt 14.

ANON 1991 Doppers se dilemma, stem van Potch is stil. Insig. 10-12, Mei.

BARADAT, L.P. 1991 Political ideologies. Their origins and impact. 4th ed. Englewood Cliffs : Prentice Hall.

BARNARD, S.S. 1992. Intreerede, Wetenskaplike Bydraes, Reeks H, PU vir CHO, Potchefstroom. p. 1-28

BOTHA, ME. 1995. Christelike universiteit en politiek in 'n apartheids- en postapartheidsbedeling. Koers, $60(2): 121-148$

BOESAK, A. ca. 1975. De moet om zwart te zijn en de strijd om bevrijding. ( $I n$ Boesak, A Om het zwart te zeggen Een bundel opstellen over centrale themas in de Zwarte theologie Kampen : Kok. p 29-44.)

BRITZ, RM. 1992. Ingebeelde singewing Die begrip 'Calvinisme' in die Afrikaanse geskiedskrywing van die $20 \mathrm{e}$ eeu (In Konferensiebundel van die Suid-Afrikaanse Historiese Genootskap Bloemfontein : UOVS. Januarie p. 34-39.)

COETZEE, J.H. s.j Die Calvinisme en volkeverhoudinge. Potchefstroom : PU vir $\mathrm{CHO}$ Instituut vir die bevordering van Calvinisme.

DE KLERK, P. 1973. Geskiedenisvergelyking, die gebruik van vergelykende metodes wat gerig is op generalisasie in die geskiedkunde. Pretoria RGN

DE KLERK, P. 1981. Geskiedenis as kultuurontwikkeling. Durban : Butterworth.

DE KLERK, P 1987 Paradigmas in die Geskiedwetenskap (In Paradigmas in die wetenskappe. 'n Christelike perspektief. PU vir CHO. Feesbundel, Dept. Wetenskapsleer. Potchefstroom : PU vir CHO. p. 45-50.)

DE KLERK, P. 1992. Die eenheid van die Geskiedenis. Wetenskaplike Bydraes, Reeks H Potchefstroom : PU vir $\mathrm{CHO}$ p $1-28$

DE KLERK, $P$. 1994. Van Eurosentriese na Afrosentriese geskiedenis - is daar 'n alternatief? Koers, 59(1):53-68

DIE VOORTSETTINGSKOMITEE. 1987. Geloof en protes Pretoria : Aurora Pers.

DREYER, P S 1974. Inleiding tot die filosofie van geskiedenis Kaapstad: HAUM.

DU PLESSIS, J.S. 1992. (In Konferensiebundel van die Suid-Afrikaans Historiese Genootskap. Bloemfontein : UOVS. p. 36 )

ENGELBRECHT, E. 1995. Jan van Riebeeck en Voortrekkers was grondstelers. Rapport 9, Okt. 29.

ESTERHUYSE, W P. 1987. Die funksies van ideologie ( $l$ Esterhuyse, W.P. et al. Moderne politieke ideologiee. Johannesburg : Southern. p. 313-314.)

HARRIS, HE 1964. Christianity and history New Jersey: Princeton.

HAT

$K y k$

ODENDAL

HELBERG, J.L. 1981. Die beginsel van ware wetenskap is oorgawe aan God Potchefstroom : PU vir CHO (Interprelasie en oorded, Reeks J, Lettere en Wysbegeerte. No. 91.)

HEIBERG, P J. s.j. Christelike opvoedings- en onderwyspraktyk en Christelike Opvoedkunde Potchefstroom : PU vir CHO (Instituut vir die bevordering van Calvinisme, Studiestuk nr. 42.)

HOFMAN, H.A. 1990 Constant Huygens Transparamt, 1(2):5 
Elize S. van Eeden \& C.J. Coetzee

HOFMEYR, J.H 1992 ( $\mathrm{m}$ Konferensiebundel van die Suid-Afrikaans Historiese Genootskap Bloemfontein : UOVS. Januarie. p. 36.)

HORN, J M L. 1986. 'n Nuwe geskiedenis. Gister en Vandag : 12, Sept

HOWARD RIENSTRA, M 1977 History, objectivity and the Christian scholar Fides et Historia, 10(1) 7-25, Fall

INSTITUTE FOR CONTEXTUAL THEOLOGY. 1990 Violence, the new KAIROS Johannesburg : Skotaville

KAPP, P H \& MOLL, J.C. et al. 1988. Geskiedenis van die Westerse beskawing, deel I Oorsprong tot intellektuele rewolusie Pretoria : HAUM.

LIEBENBERG, S B \& SPIES, B J eds. 1993 South Africa in the 20th century. Pretoria Van Schaik.

LION-CACHET, F. 1992 ( $/ \mathrm{l}$ Konferensiebundel van die Suid-Afrikaans Historiese Genootskap Bloemfontein: UOVS Januarie. p. 36.)

MATTHEW, D 1954 Lord Acton and his times. (/n Thompson, J.W. A history of historical writing, vol. II New York : Macmillan Company. p. 360.)

McMANNERS, J ed. 1992. The Oxford illustrated history of Christianity New York Oxford University Press

McNELLY, T, 1993. The government of Japan. (In Curtis, M. ed Introduction to comparative government 3rd edition New York Harper Collins. p 273.)

MILBURN, R L.P 1954 Early Christian interpretations of history. London : Adam \& Charles Black.

MULLER, C.F.J. 1987. 500 Jaar Suid-Afrikaanse geskiedenis Kaapstad : Nasionale Boekdrukkery.

NIEBUHR, $R \mathrm{~s}$. Faith and history A comparison of Christian and modern views of history London : Nisbet.

ODENDAL, F.F. hoofred. 1988 Verklarende handwoordeboek van die Afrikanse taal. Johannesburg : Perskor

OUWENEEL, W.J 1993 Is 'n Christelike universiteit moontlik? Koers, 58(3):323-336, Sept

PU vir CHO Raad 1994. Numsbricf: I-6.

PU vir CHO. 1987. Feesbundel. Paradigmas in die wetenskappe, 'n Christelike perspektief. Potchefstroom : Dept. Sentrale Publikasies.

RÜSEN, J. 1991 Historical education in a multicultural society. Gister en Vandag, 21:1-6, April.

SCHAEFFER, J 1990 De geschiedbeschouwing van Groen van Prinsterer Transparant, 1(4) 9

SMITH, K. 1988 The changing past Trends in South African historical writing Cape Town : Southern Book Publishers

VAN DER MERWE, D C S 1977 Swart teologie en die volheid van God in Jesus Christus. Woord en Daad 12-16, Oktober

VAN DER VYVER, G.C P. 1976 Teologie Potchefstroom: PU vir CHO. (Wetenskaplike bydraes van die PU vir CHO. Die geskiedenis en die wetenskap. Reeks A. Geesteswetenskappe nr. 22:130-132.)

VAN DER WALT, B J. 1990 Om mens te wees, gawe en opgawe. Potchefstroom : Dept Sentrale Publikasies.

VAN DER WALT, B J. 1994. A Christian approach to the diversity in political viewpoints, religions and cultures - illustrated by way of a case study of South Africa ( $m$ Van der Walt, J L ed. Konferensiebundel Multicultural education: New challenges for South Africa, 4-6 Augustus p. 51-66.)

Koers 61(3) 1996:271-290 
Aspekte van 'n Christelike perspektief op fasetle van die Geskicutictenskap ...

VAN DER WALT, JL 1995 Die opvoedingsfilosofiese grondslae van multikulturele onderwys. Koers, 60(1) 41-51

VAN JAARSVELD, F A 1964. The Afrikaners' interpretation of South African history. Cape Town : Simondium.

VAN JAARSVELD, F A 1984 Geskiedenisideologie, omstrede Suid-Afrikaanse verlede en historiese skuldvraagstuk Johannesburg : Lex Patria

VAN JAARSVELD, FA 1990a. Nuwe SA noodsaak nuwe blik op geskiedenis Beeld, Junie 5.

VAN JAARSVELD, F A 1990b. Skoolgeskiedenis in die nuwe Suid-Afrika. Gister en Vandag, 20:3-8, Sept

VAN LEEUWEN, A Th 1966. Het christendom in de wereldgeschiedenis Amsterdam : Edinburgh House Press

VAN NIEKERK, L. \& MEIER, C. 1994 Die invloed van die New'Age-beweging op die onderwysagenda van die toekoms Koers, 59(1) 69-84

VAN WIJK, T \& SPIES, S B et al. 1985 Western Europe from the decline of Rome to the Reformation. Pretoria : Academica

WIESE, T 1995. Geestelike herlewing oral in Suid-Afrika Insig 12-13, Maart

WOLFFE, J.R 1990. Christian history in Britain and the Netherlands Transparant, 1(2):38

WOLTERS, A.M. 1992 Die skepping herwin Bybelse grondslae vir 'n reformatoriese lewensbeskouing (Vertaal deur dr PD van der Walt.) Potchefstroom : Sept. Sentrale Publikasies. 